\title{
Implicit persuasion of voters in the 2012 Slovak republic parliamentary elections
}

\section{Lukáš Cíbik ${ }^{1}$}

\begin{abstract}
The aim of the article is to see the degree of implicit position and value correlation between the voters of particular political parties in Slovakia (SMER-SD, SaS, and SDKÚ-DS). The free association method is supposed to reveal implicit purposes of individual political issues, beliefs and values in the eyes of their voters. Social representations, public discourse and implicit purposes objectified and anchored in civil society by the political elites are obtained by the discrete association method. The focus is held on the importance of political discourse for the voters to take note in the decision-making process in the election to the Parliament of the Slovak Republic in 2012.
\end{abstract}

Key words: voters, implicit persuasion, Slovak republic, political parties

\section{INTRODUCTION}

Over the last few years we have seen a growing trend towards reviewing implicit persuasion of voters in literature. This approach in political science is practised especially with reference to election surveys. This is due to improving the prediction accuracy of election results, as well as understanding social and cultural discourses, i.e. the social order to which political parties react. On the other hand, the analysis of implicit persuasion of Slovak voters states the degree of identifying to the discourse being made by a political party. A.G. Greenwald and M. R. Banaji (Félix 2009) state that by realizing the fact that the human mind is more than just a set of conscious process a large number of theories holds the main focus on the conceptual differences between evaluations that are seen either as a product of introspection called explicit approaches, or as a product of evaluations that occur automatically and exist outside of conscious awareness called implicit approaches. I.Burdein (Burdein, Lodge \& Charles 2006) indicates that below the answer to the question of a citizen survey there are countless automatic responses that will never be consciously perceived. Survey questions on socially sensitive issues are subjected to conscious social conformity and self-presentation bias. In short, reliance of surveys on conscious, introspective considerations which act as mediators of conduct fails to shape how people think, act, and assume.

1 Mgr. Lukáš Cíbik, Department of Public Policy and Public Administration, Faculty of Social Sciences, University of Ss. Cyril and Methodius in Trnava, Bučianska 4/A, 91701 Trnava, Slovak Republic. E-mail: lukascibik.ucm @gmail.com 
A. T. VanDjik (2003) indirectly points to the importance of implicit and automatic processes. He indicates that discourses are like icebergs in which only a small number of meanings, purposes is expressed. The other information and purposes may be tacitly assumed and therefore remain implicit. In other words, recipients of the same culture are able to deliver this implicit information to their own event model. The semantic (explicit) representations that define the 'purpose' of discourse are only a small selection of information represented in the model used to understand this discourse. A. T. VanDjik (2003) calls the attention to the fact that by discerning only explicit characteristics we cannot capture the entire depth of a particular discourse. For this reason it is significant to examine its implicit measures. It is also necessary to point to the commonly held fact of the survey which is marks as an environment into which an individual is inserted. These commonplaces are brought up naturally by individuals during the conversation exchange, with no attitude of critical appreciation and reflection on their origin, i.e. on their correctness.

The central point of the research is to explore political values and beliefs, with the corresponding area of focus on implicit or automatic processes and their linking to political views and positions of the participants. J. A. Bargh (Burdein, Lodge \& Charles 2006) highlights a pragmatic framework for the research on automatic processes mainly in relation to persuasion, while pointing out the need to link laboratory findings with the practical areas of life. In relation to persuasion, the knowledge of automatic effects exploited for commercial and imperial purposes is considered to be dangerous. We are witnessing diverse political statements which give us the impression that it is always essential to follow a particular statement and appreciate it surely. What is equally disheartening is the fact that voters regardless of relevant information follow the political leaders with excellent communication skills and impressive persuasive statements. For this reason, the author's view on the need to understand the mechanisms of persuasion in the general public is important as well as the author's view on the danger of persuasion exploited for political purposes.

B. Zajonc (Albertson 2011) states that one of the classic examples of the implicit way to shape views, positions and values is the exposure itself, or the fact that positive views and attitudes can be formed through a repeated exposure to a new object.

R. L. Moreland and S. R. Beach (1992) carried out an experiment in which four women with a diverse frequency were supposed to join lectures and seminars at a university. At the end of the term the students' assessment record showed that women with the most successful attendance were regarded the most attractive despite the fact that their presence did not affect the self-reported - 
knowledge stated in explicit statements. The effect of exposure is explained by the fact that a repeated exposure strengthens representations of new objects in the minds of students (in this case women), which leaves the students process visions of those women more easily. The positive feeling which comes from a reinforced perceptual fluency is associated with the new object. It is important, however, that this mechanism is implicit because the students had no idea that the representations of women were built in their memories and in most cases, the women were not recognized at a conscious level.

The mechanism of exposure itself and the exposure's impact on forming implicit views and attitudes is significant notably in relation to pre-election campaigns and numerous billboards in many cities. The following research promotes an analysis on the free association research.

The premise of the research is that a common way of thinking is represented by the same associations (or semantically related) which are produced first within a particular group of members. These members assign the utmost importance to the greatest number of identical stimulus words. The research starts from the assumption that the more similar dictionaries are, the more related social representations are among the participants.

\section{SCIENTIFIC METHODS}

The methods which are used in the study of social representations include the group association method and its multiple variations, in this case the discreet association method (Plichtová 2002). The research is aimed at the analysis of associations at a group level as well as the analysis of selecting individual stimulus words by the subjects with a particular level of importance allocated by them. The data obtained in this way may provide us with information on the degree of internal homogeneity groups as well as information on the intergroup comparison. In accorodance with J. Plichtová (2002) we assume that the more homogeneous internally the group is, the more related are associations of its members, while the selection of the stimulus words of the highest importance is thus narrower within the entire group.

The particular study is inspired by DiGiacomo's work. By using the group association method the degree of homogeneity of a student movement, or a committee was examined. The author starts from the assumption that if the students and their leaders are thinking alike on a particular situation, the movement is likely to retain its position (Plichtová 2002).

The second study acts as an incentive to explore the particular issue. The 
research is conducted by Marková, Plichtová and Moody in two countries. The work is aimed at exploring and understanding the notion of democracy (implicit, explicit) (Plichtová 2002).

The group discrete associations method is dominant in the research project as a possible indicator of the implicit sense of belonging to individual political ideologie/parties. For this purpose we have chosen 23 socio-political terms to which a certain kind of importance is attached by individual political parties/ ideologies.

The participants were asked to provide only one association for each of the 23 stimulus words. That procedure was chosen in order to find out whether there is a common way of thinking within individual groups. The second part of the research includes a selection of the most important stimulus words being suggested by the participants themselves.

Processing the research answers we created a list of associations (dictionary) on the basis of inciting efforts of the stimulus words within individual groups as well as a list of repeated stimulus words to which the highest importance was attached. The next step of the research is the analysis of the stimulus words to which the highest importance is attached. The research is seeking to draw several connections:

a) A quantitative account of individual stimulus words to which the highest importance is attached (considering the size of the group we will provide you with the quantitative analysis of the stimulus words which are present more than twice in the list);

b) Which associations (and, where appropriate, an umbrella topic) are created to cover these stimulus words and to what extent the associations are identical within the group. We assume that this part of the work will outline social representations of individual concepts (which are significant for a particular group) that are being represented through associations. In accordance with Plichtová (2002) the work starts from the assumption that the participants make a general way of speaking about a particular concept (they do not promote their private discourse since the private discourse always appears after a general way of speaking about a particular topic has dried up). We also conclude that the more general the way of speaking about a particular topic is (more general linguistics in a local, cultural community), the more used it is by the participants. The frequency sequence on the basis of which various associations occur in the production of the participants indicates the way of speaking about a particular topic and what discourses are well-established in a local community. (Plichtová 2002, p. 63);

c) Linking the selection of stimulus words (along with related associations) with 
party ideology and party marketing promotion;

d) Noticing the degree of semantically related stimulus words selected by the subjects through the use of their association correlation and their subsequent analysis.

\section{PROCEDURE AND STATISTICAL PROCEDURES}

The participants of the survey were contacted via Internet. For this purpose an extensive e-mail database was used for exploration purposes. The database consisted of 100,000 email addresses. Despite a considerable extent, however, the return of completed surveys was relatively low. Additionally, it did not go beyond $1 \%$, which is the percentage normally achieved in current surveys.

This may be due to the time constraints to complete a piece of survey (about 30minutes). Moreover, in the completed surveys an obvious lack of interest in political issues was observed.

Email addresses in the database were obtained on the basis of voluntary registration of citizens to participate in opinion polls.

The research data was gathered during three months. The participants were contacted via social networks during the first month of that period, while during the last two months the research documents were being sent out to specific e-mail addresses.

To collect the research data, a special software was created for the purpose of contacting the authors immediately if in doubt about any point. The system registered only completed surveys and did not provide any repeated option for a particular participant to start the survey test again.

Despite the fact that the research plan envisaged an equal number of participants for individual political parties, from a point of view the number of obtained data might be parallel to the election results in 2012 as well as to a cross-society attitude towards political issues as such (the largest number covers: 1. non-voters, 2. voters of the SMER-SD party 3. SDKÚ-DS and SaS voters were represented approximately by equal participation).

The sample of 422 participants is not a representative sample of the population, notably due to the fact that participating in the research was determined by the use of Internet access as well as by a personal drive to be involved in timeconsuming tasks.

Before the analysis of associations is discussed, it is important to know why the attention is paid to the first six essential concepts highlighted by voters. The main reason is the concept of social representations. The concept puts a high 
premium on commonly shared values in a particular social community.

The second reason is limited room which has been used to underscore intergroup differences on the semantic structure of particular concepts made by individual groups. The following question is this: is the content and the semantic structure of concepts in agreement with social or party discourse?

In the analysis the sequence of concepts is provided as follows: concepts $\rightarrow$ of the highest importance within each group, concepts $\rightarrow$ common within 2 groups, concepts $\rightarrow$ specific for individual groups of voters.

The values obtained are summarised in the tables and figures (with individual results being given in percentages in the graphs).

In essence, the intention is to describe individual association categories, i.e. differencies/similarities in social representations within individual groups of voters, as well as to identify public discourse, social representations anchored in society, or produced by the political elites, in particular, through the use of billboards and to analyze their correlation. By measuring the closeness of agreement between implicit values, beliefs and views of the voters in relation to the pre-election promotion (mainly by billboards) we propose the intersubjective consensus approach. The analysis is aimed at the degree of agreement between socio-political values, beliefs, views within individual groups of voters and values, beliefs, views (mainly by billboards) within the political parties.

\subsection{Family (SMER-SD, SDKÚ-DS, SaS)}

The concept of family appears to be the most appreciated value for each group of voters being surveyed. After performing the analysis of concept associations we may fairly conclude that associations generated for this concept are parallel to a natural discourse which fits the family in our culture and our socio-cultural conditions. The value of family is believed to be firmly anchored in Slovak society regardless of sympathizing with individual political ideologies. Despite this, however, certain specificities characterizing the particular groups of voters were noticed.

Analyzing the semantic structure of concepts within individual voters we may fairly conclude that common to each group are social representations for the concept of family with a strong bond and love for individual members, which resulted in appointing a family member. 
Graph 1: Concept of family - social representations (\%)

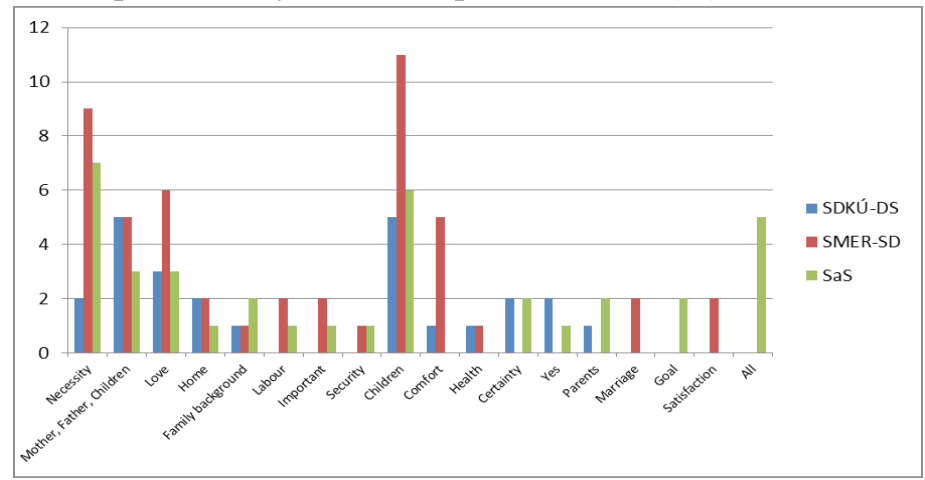

Source: author

Table 1: Concept of family - semantic closeness

\begin{tabular}{|c|c|l|}
\hline Political party & $\begin{array}{c}\text { Associati } \\
\text { on }\end{array}$ & \multicolumn{1}{|c|}{ Stimulus word } \\
\hline SMER-SD & Children & social security, responsibility \\
\hline SMER-SD & Necessity & $\begin{array}{l}\text { vested interest, sui juris, labour, labour rights, hu- } \\
\text { man rights, voter participation, good society, soli- } \\
\text { darity, minority rights, equal opportunities, discus- } \\
\text { sion }\end{array}$ \\
\hline SMER-SD & Love & solidarity, equality \\
\hline SaS & Necessity & $\begin{array}{l}\text { discussion, labour rights, sui juris, labour, responsi- } \\
\text { bility, democracy, hierarchy, social security, voter } \\
\text { rights, solidarity, freedom, welfare state, vested in- } \\
\text { terest, corruption, poverty }\end{array}$ \\
\hline SDKÚ-DS & Certainty & social security, responsibility, sui juris \\
\hline
\end{tabular}

Source: author

Common to SMER-SD and SaS voters is an associative word production for the concept of family by using the associative word need, necessity through the use of which they promoted identical social representations on the one hand, but on the other hand there were differences in the semantic structure. Common to either group are clusters of meanings and semantic structures which are part of the following thematic sets and are regarded as need/necessity by the voters 
(need/necessity as the main association). We assume that the semantic structure represents a pattern of the ideal society, or its vital aspects: good society, human rights, solidarity, voter participation, a sense of fellowship, discussion, labour rights, vested interest. Basically, there is a tendency to discuss social issues since the citizens of Slovakia perceive a long-term shortage of the social aspects (labour, solidarity, etc.).

The most frequent correlation between the concept of family and the concept of discussion under the main association of need/necessity, in relation to quantity, becomes a specific feature within identical representations among the $\mathrm{SaS}$ voters. This may fundamentally be linked to the SaS's philosophy to promote a chance to debate, or to communicate virtually as well as to offer a chance to debate directly with voters (debates in school dormitories).

As far as identical representations among the SMER-SD voters are concerned, in relation to quantity, under the main association of need/necessity the concept of vested interest is highlighted. As a matter of fact, this is a mere contrast to the socialist principles the SMER-SD party holds dear. Furthermore, it is expected as more relevant representation among $\mathrm{SaS}$ voters.

In this part, the main focus is held on the specific semantic structures among SMER-SD and SaS voters. From this point of view, surprisingly the SaS voters make structures which do not adhere to their liberal ideological foundations. These structures unequivocally cover semantic closeness of the concept of family with the concepts of hierarchy, welfare state, social security.

What is regarded as a specific feature among the SDKÚ-DS voters is the semantic correlation between the concepts of family and social security under the main association of need/necessity.

\subsection{Labour (SMER-SD, SDKÚ-DS, SaS)}

The concept of labour was dominant in relation to the degree of relevance for each group being surveyed. The choice of the concept was based on the fact that in pre-election campaigns the concept of labour was used by each political party being surveyed. In spite of the fact that this phenomenon is seen as normal in relation to the serious underemployment, we do not hesitate to see social representations for the concept of labour in the eyes of the voters. The concept of labour is the second most relevant concept among SMER-SD voters. Among SaS voters the concept of labour becomes the third most important concept. Among the SDKÚ-DS vote takers the concept of labour is the second most important concept. 
Analyzing the semantic structure of concepts within individual groups of voters one may fairly conclude that common to each group are social representations for the concept of labour seen as the concept of need/necessity and money. The semantic correlation is outlined in the previous categories, in relation to the semantic structure by using the main association of need/necessity.

Common to each group of voters is the aforementioned associative production for the concept of labour by using the stimulus word money through the use of which they promoted identical social representations on the one hand, but on the other hand there were differences in the semantic structure. Common to each group is a semantic correlation between the concepts of labour and corruption under the main association of money. From our point of view, the main association of money portrays to a considerable extent a superficial, common understanding of the word labour as a source of money. Generally, money is viewed in a negative sense, as shown by the semantic correlation. One may assume that the correlation between corruption and money reflects several detected corrupt practices since the word money is repeatedly mentioned in the media and society as a whole.

Graph 2: Concept of labour - social representations (\%)

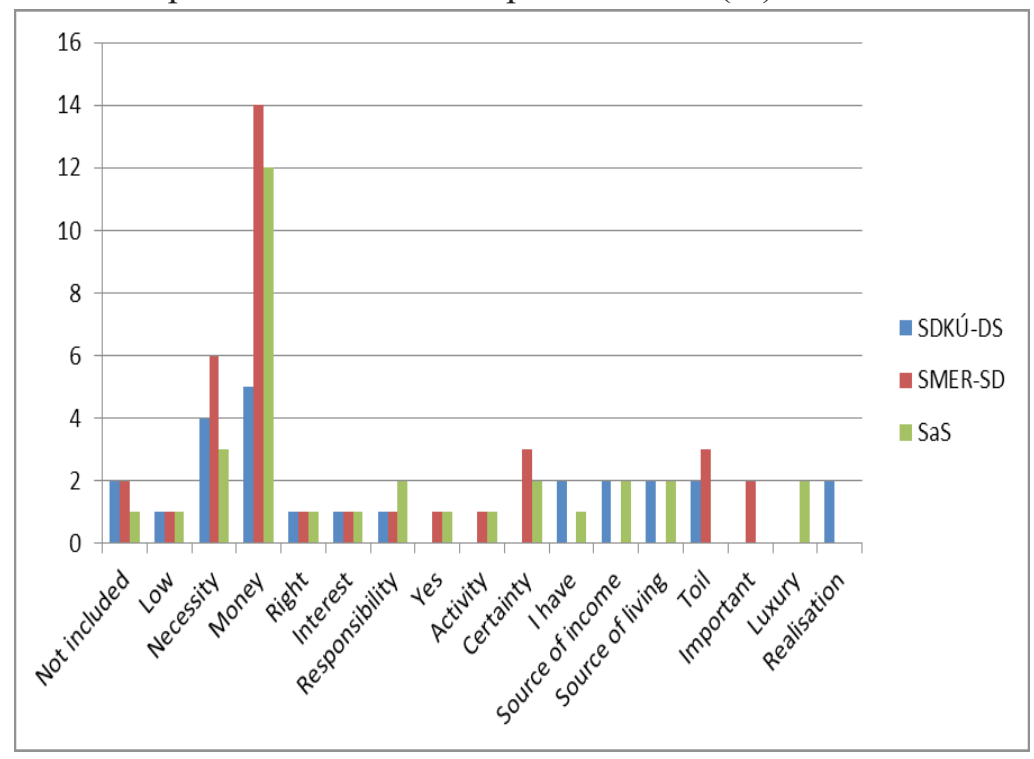

Source: author 
Table 2: Concept of labour - semantic closeness

\begin{tabular}{|c|c|c|}
\hline $\begin{array}{c}\text { Political } \\
\text { party }\end{array}$ & Association & Stimulus word \\
\hline $\begin{array}{l}\text { SMER- } \\
\text { SD }\end{array}$ & Money & $\begin{array}{l}\text { corruption, social security, democracy, good society. } \\
\text { prosperity for all, equal opportunities, vested interest }\end{array}$ \\
\hline $\begin{array}{l}\text { SMER- } \\
\text { SD }\end{array}$ & Necessity & $\begin{array}{l}\text { labour rights, sui juris, voter participation, good society, } \\
\text { solidarity. human rights, vested interest, discussion, equal } \\
\text { opportunities }\end{array}$ \\
\hline $\begin{array}{l}\text { SMER- } \\
\text { SD }\end{array}$ & Important & $\begin{array}{l}\text { sui juris, human rights, freedom, labour rights, responsi- } \\
\text { bility }\end{array}$ \\
\hline $\begin{array}{l}\text { SMER- } \\
\text { SD }\end{array}$ & Certainty & $\begin{array}{l}\text { social security, labour rights, good society. human rights. } \\
\text { responsibility, welfare state }\end{array}$ \\
\hline $\mathrm{SaS}_{\mathrm{S}}$ & Moncy & $\begin{array}{l}\text { good society. prosperity for all, responsibility. welfare } \\
\text { statc, social security, cormption }\end{array}$ \\
\hline SaS & Necessity & $\begin{array}{l}\text { democracy, discussion, sui juris, hierarchy, labour rights, } \\
\text { social security, voter participation, family, democracy, } \\
\text { good society, human rights, solidarity, freedom, welfare } \\
\text { state, vested interest, corruption, poverty, responsibility }\end{array}$ \\
\hline SaS & Luxury & social security. good society \\
\hline SaS & $\begin{array}{l}\text { Responsibil- } \\
\text { ity }\end{array}$ & sui juris \\
\hline SDKÜ-DS & $\begin{array}{l}\text { Does not ex- } \\
\text { ist }\end{array}$ & $\begin{array}{l}\text { solidarity, labour rights, sui juris, vested interest, human } \\
\text { rights, voter participation, discussion, freedom, hierarchy, } \\
\text { equal opportunities }\end{array}$ \\
\hline SDKÚ-DS & $\begin{array}{l}\text { Does not ex- } \\
\text { ist }\end{array}$ & $\begin{array}{l}\text { discussion, vested interest, equal opportunities, good soci- } \\
\text { ety, prosperity for all, minority rights, responsibility. } \\
\text { equality, freedom, social security. labour rights }\end{array}$ \\
\hline SDKÚ-DS & Money & corruption \\
\hline
\end{tabular}

Source: author

Common to the SMER-SD voters and the SDKÚ-DS voters is an associative word production for the concept of labour by using the word toil through the use of which, however, they did not produce any other semantic correlation.

The concept of labour seen as a source of values and personal fulfillment becomes a specific feature among the SaS and the SDKÚ-DS voters.

Individual groups produced specific semantic structures in relation to other 
social representations for the concept of labour. We are selecting only those which are considered to be important in some way. The concept of labour seen as a source of funds becomes a specific feature among the SMER-SD voters as well as there is a strong correlation portrayed between the concept of labour and the concept of social security, welfare state, labour rights under the main association of certainty. We assume that the described cluster reflects the party identification and internalisation of the conceptual apparatus through the use of which the party manifests itself mainly by billboards.

\subsection{Responsibility (SMER-SD, SDKÚ-DS, SaS)}

The concept of responsibility was dominant in relation to the degree of relevance for each group being surveyed. From our point of view, the concept itself is significant in relation to politics. It will be interesting to evaluate how the notion of politics (the role of internal and external factors) is perceived within each group of voters. The concept of responsibility becomes the third most relevant concept among the SMER-SD voters. Among the SaS voters the second most important concept is the concept of responsibility. Among the SDKÚ-DS voters the concept of responsibility becomes the third most important concept.

Graph 3: Concept of responsibility - social representations (\%)

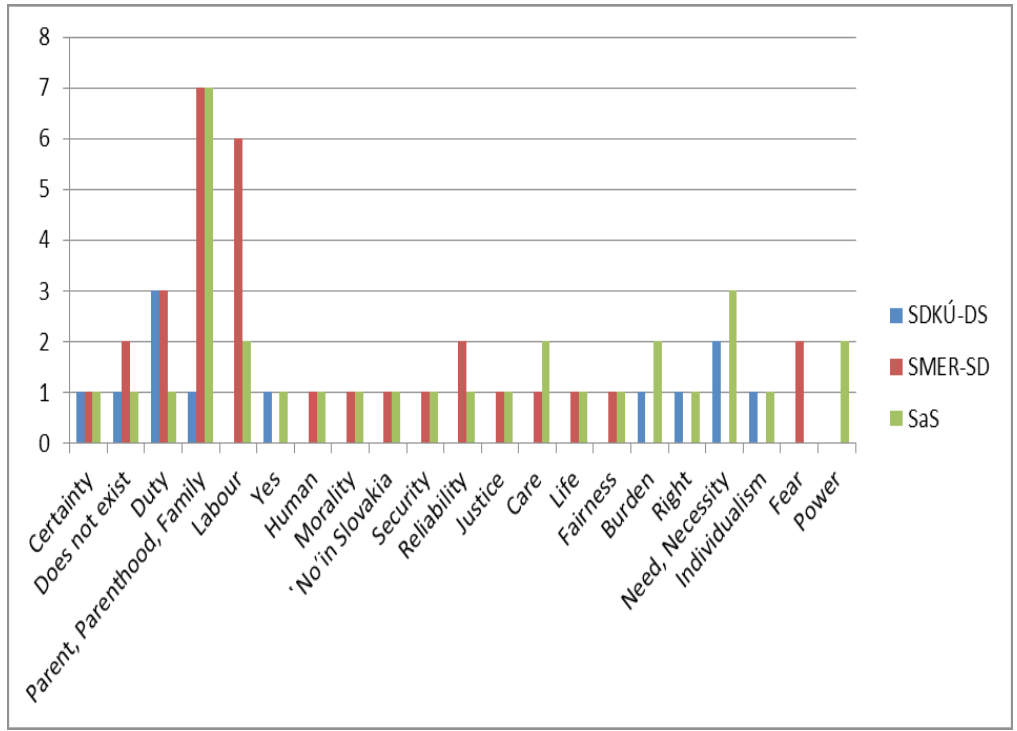

Source: author 
Table 3: Concept of responsibility - semantic closeness

\begin{tabular}{|c|c|c|}
\hline Political party & Association & Stimulus word \\
\hline SMER-SD & $\begin{array}{l}\text { Parent, } \\
\text { Parenthood, } \\
\text { Family }\end{array}$ & vested interest, good society, hierarchy, solidarity \\
\hline SMER-SD & Duty & $\begin{array}{l}\text { human rights, minority rights, social security, vested } \\
\text { interest }\end{array}$ \\
\hline $\mathrm{SaS}$ & $\begin{array}{l}\text { Parent, } \\
\text { Parenthood, } \\
\text { Family }\end{array}$ & social security, solidarity, hierarchy \\
\hline $\mathrm{SaS}$ & $\begin{array}{l}\text { Need, Neces- } \\
\text { sity }\end{array}$ & $\begin{array}{l}\text { family, discussion, sui juris, labour, labour rights, } \\
\text { democracy, hierarchy, social security, voter partici- } \\
\text { pation, democracy, good society, human rights, soli- } \\
\text { darity, freedom, welfare state, vested interest, cor- } \\
\text { ruption, poverty }\end{array}$ \\
\hline $\mathrm{SaS}$ & Power & welfare state, solidarity, media, corruption \\
\hline $\mathrm{SaS}$ & Labour & $\begin{array}{l}\text { equal opportunities, labour, hierarchy, labour rights, } \\
\text { equality, social security, family, discussion }\end{array}$ \\
\hline SDKÚ-DS & $\begin{array}{c}\text { Need, Neces- } \\
\text { sity }\end{array}$ & $\begin{array}{l}\text { solidarity, labour rights, sui juris, vested interest, hu- } \\
\text { man rights, discussion, freedom, hierarchy, equal op- } \\
\text { portunities, labour }\end{array}$ \\
\hline SDKÚ-DS & $\begin{array}{l}\text { Parent, } \\
\text { Parenthood, } \\
\text { Family }\end{array}$ & equality \\
\hline
\end{tabular}

Source: author

Analyzing the semantic structure of concepts within individual groups of voters we may fairly conclude that common to each group are social representations for the concept of responsibility complying with the associative word parent, parenthood, family through the use of which they promoted identical social representations on the one hand, but on the other hand there were differences in the semantic structure. From our point of view, however, the representation categories are peculiar to our society and culture in which an individual is expected to be responsible for his family, while at the same time family is believed to teach an individual responsibility.

Only among SaS and SMER-SD voters, in our culture, there is a common correlation portrayed between the concept of responsibility and the concept of 
hierarchy, a sense offellowship under the main association of parent, parenthood, family. In contrast to this semantic structure we are compelled to point to the interconnection with the concept of equality among the SDKÚ-DS voters. As to the outlined semantic structure the definition of positions is perceived as a peculiar feature since the SMER-SD voters combine responsibility with vested interest, while the SaS voters define responsibility as a sense of fellowship.

Among the SMER-SD voters, the semantic closeness of the concepts of responsibility, vested interest, good society is considered to be interesting (under the main association of parent, parenthood, family). These concepts are represented in a fair correlation between an individual and society in the eyes of the voters. In addition to this, an individual is responsible for parenthood as well as is determined to defend their interests with the aim to build a fair society.

Among SaS voters, there is a specific correlation between the concept of responsibility under the main association of power and the concepts of media, corruption, solidarity, welfare state. In this context, responsibility, being the external factor, cannot be viewed from the I' position.

\subsection{Human rights (SMER-SD, SDKÚ-DS, SaS)}

Graph 4: Concept of human rights - social representations (\%)

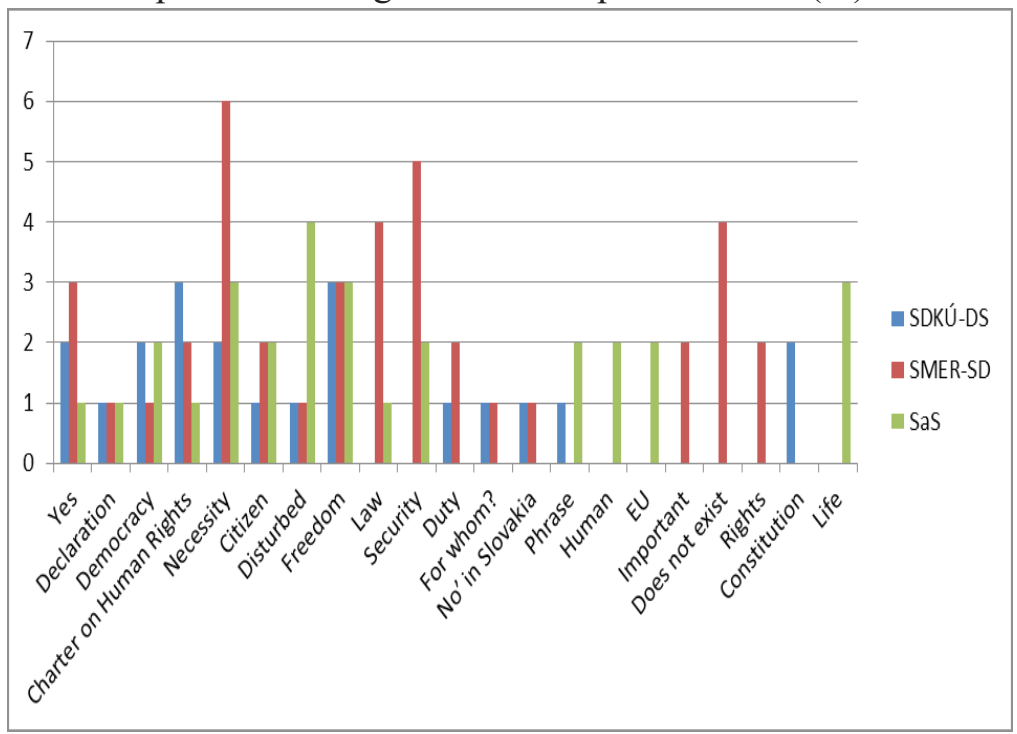

Source: author 
Table 4: Concept of human rights - semantic closeness

\begin{tabular}{|c|c|c|}
\hline $\begin{array}{l}\text { Political } \\
\text { party }\end{array}$ & $\underset{n}{\text { Associatio }}$ & Stimulus word \\
\hline SMER-SD & Necessity & $\begin{array}{l}\text { labour, sui juris, labour rights, voter participation, soli- } \\
\text { darity, good society. vested interest, discussion, equal } \\
\text { opportunities }\end{array}$ \\
\hline SMER-SD & Freedom & $\begin{array}{l}\text { democracy, freedom, sui juris, labour rights, minority } \\
\text { rights, equality. vested interest, equal opportunities, re- } \\
\text { sponsibility }\end{array}$ \\
\hline SMER-SD & Law & labour rights, responsibility. sui juris \\
\hline SaS & Security & $\begin{array}{l}\text { Sui juris, hierarchy, responsibility, labour rights, minor- } \\
\text { ity rights }\end{array}$ \\
\hline $\mathrm{SaS}$ & Freedom & $\begin{array}{l}\text { democracy, sui juris, equal opportunities, freedom. } \\
\text { equality }\end{array}$ \\
\hline $\mathrm{SaS}$ & Life & freedom, responsibility, family, labour \\
\hline $\mathrm{SaS}$ & Democracy & $\begin{array}{l}\text { discussion, minority rights, equal opportunities, free- } \\
\text { dom, voter participation, } \\
\text { sui juris }\end{array}$ \\
\hline $\mathrm{SaS}$ & Necessity & $\begin{array}{l}\text { family, discussion, sui juris, hierarchy, democracy, la- } \\
\text { bour rights, social security, voter participation, democ- } \\
\text { racy. good society. solidarity. freedom, welfare state, } \\
\text { vested interest, comuption, poverty. responsibility. la- } \\
\text { bour, good society }\end{array}$ \\
\hline SDKÚ-DS & Necessity & $\begin{array}{l}\text { solidarity, labour rights, sui juris, vested interest, voter } \\
\text { participation, discussion, freedom, hierarchy, equal op- } \\
\text { portunities, labour, responsibility }\end{array}$ \\
\hline SDKÜ-DS & $\begin{array}{c}\text { Constitutio } \\
\mathrm{n}\end{array}$ & welfare state, minority rights \\
\hline
\end{tabular}

Source: author

Analyzing the semantic structure of concepts within individual groups of voters we may fairly conclude that common to each group are social representations for the concept of human rights complying with the stimulus word need/necessity. The semantic correlation is outlined in the previous categories, in relation to the semantic structure by using the main association of need/necessity. In the previous category the focus was held on semantic structures among the SMER$\mathrm{SD}$ voters. In consequence of that it is necessary to provide the results of the 
SDKÚ-DS party which show no compliance with the results of the SMERSD party in the previous category; semantic structures shared with each group of voters are labour, solidarity, sui juris, voter participation, labour rights, discussion. Moreover, there is the semantic correlation between human rights and freedom, hierarchy and responsibility as to the semantic structures shared with the $\mathrm{SaS}$ vote takers. Additionally, it is interesting to highlight need/necessity and hierarchy/responsibility as a sign of party identification. Furthermore, there is a strong agreement between human rights and equal opportunities as to the semantic structures shared with the SMER-SD vote takers.

Common to the SaS and the SMER-SD voters is an associative word production for the concept of human rights by using the stimulus word freedom and low, or disturbed through the use of which they promoted identical social representations, but on the other hand there were differences in the semantic structure. In relation to the association of freedom common to either group are semantic structures for the concepts of democracy, sui juris, equal opportunities, freedom and equality.

There is a specific correlation between the concepts of minority rights, labour rights, vested interest, responsibility among SMER-SD voters. We assume that most of the semantic structures reflect a common understanding of the concept of human rights (with the exception of the concept of labour rights) which are related to socialist ideologies (social democracy based on workers' movement).

Common to either group is an associative production of the words low, or disturbed. In this point, there is found no semantic closeness with the other concepts among the $\mathrm{SaS}$ voters.

As to the SMER-SD voters this area of focus is well-defined referring to various spheres of life in which these are seen as disturbed, or as insufficiently appreciated, such as labour rights, equal opportunities.

\subsection{Good society (SMER-SD, SaS)}

The concept of good society becomes the fifth most relevant concept among the voters of the SMER-SD party. Among the voters of the SaS the fourth most important concept is the concept of good society. 
Graph 5: Concept of good society - social representations (\%)

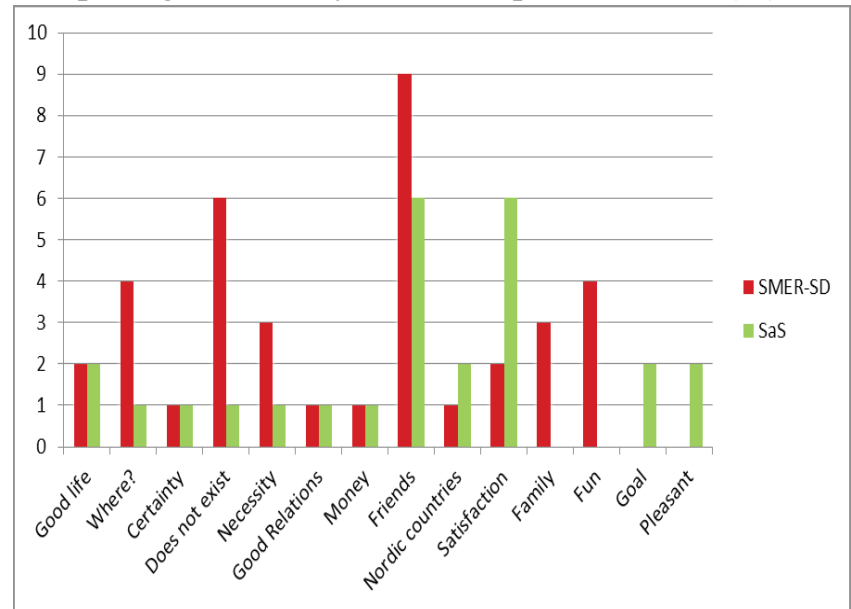

Source: author

Table 5: Concept of good society - semantic closeness

\begin{tabular}{|c|c|c|}
\hline $\begin{array}{c}\text { Political } \\
\text { party }\end{array}$ & Association & Stimulus word \\
\hline SMER-SD & Does not exist & $\begin{array}{l}\text { prosperity for all, equality, welfare state, equal oppor- } \\
\text { tunities, labour, discussion, social security, democ- } \\
\text { racy, human rights, labour rights, hierarchy, solidar- } \\
\text { ity, responsibility }\end{array}$ \\
\hline SMER-SD & Where? & $\begin{array}{l}\text { equal opportunities, social security, democracy, free- } \\
\text { dom, welfare state, prosperity for all }\end{array}$ \\
\hline SMER-SD & Fun & equality, voter participation, family \\
\hline SMER-SD & Necessity & $\begin{array}{l}\text { labour rights, sui juris, voter participation, solidarity, } \\
\text { human rights, vested interest, discussion, equal op- } \\
\text { portunities, labour }\end{array}$ \\
\hline SMER-SD & Family & $\begin{array}{l}\text { responsibility, vested interest, hierarchy, solidarity, } \\
\text { social security }\end{array}$ \\
\hline $\mathrm{SaS}$ & $\begin{array}{l}\text { Nordic coun- } \\
\text { tries }\end{array}$ & welfare state, minority rights, freedom, labour rights \\
\hline $\mathrm{SaS}$ & Goal & family, freedom \\
\hline
\end{tabular}

Source: author 
Analyzing the semantic structure of concepts within individual groups of voters we may fairly conclude that common to the SaS and the SMER-SD voters are social representations for the concept of good society complying with the stimulus words need/necessity and ties between friends. The attention is being paid on the semantic structures of the other stimulus words by using the association of necessity. The association of friends does not promote any semantic structure within any group.

Having identified the semantic structures among the SMER-SD voters, we took notice of the following: on the one hand, the focus is held to promote a vision of the good society at the micro-level referring to friends, family, fun, typically within our culture, but on the other hand there has been identified prevailing sceptical views at the macro-level; search for that place or its nonexistence.

Among the voters of the SaS party there are specific social representations of good society portrayed as a society lying outside our country which does not mirror any direct scepticism (scepticism within the SMER-SD) but a direct illustration of particular countries.

\subsection{Democracy (SDKÚ-DS, SaS)}

Only two groups of voters place a high premium on the concept of democracy. This is an interesting finding, especially when it comes to the fact that each political party is declared to be democratic. The concept of democracy becomes the sixth most relevant concept among voters of the SaS party. Among the voters of the SDKÚ-DS the fifth most important concept is the concept of democracy and equal opportunities.

Analyzing the semantic structure of concepts among the voters of the $\mathrm{SaS}$ and the SDKÚ-DS we may fairly conclude that common to the groups are social representations for the concept of democracy complying with the stimulus words equality through the use of which they promote identical social representations on the one hand, but on the other hand there were differences in the semantic structure.

Among the voters of $\mathrm{SaS}$, there are specific social representations of the concept of democracy complying with the concepts of prosperity for all, media, good society; in this case, democracy is being defined in a negative way and therefore substituted with the words chaos, stupidity, deceit. The SDKÚ-DS vote takers mark the concept of democracy under the phrase does not exist. All in all, we assume that the representations are a sign of disappointment at the political status quo, social situation, state machinery, state management. 
Graph 6: Concept of democracy - social representations (\%)

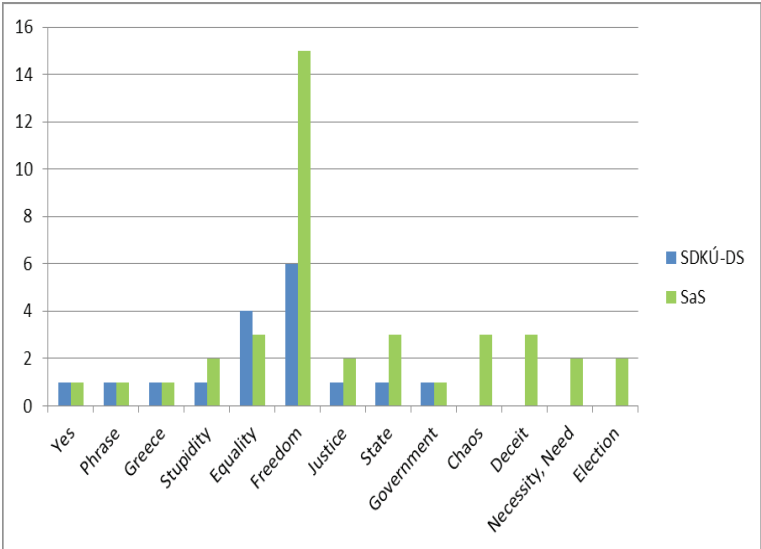

Source: author

Table 6: Concept of democracy - semantic closeness

\begin{tabular}{|c|c|c|}
\hline $\begin{array}{l}\text { Political } \\
\text { party }\end{array}$ & $\underset{\mathbf{n}}{\text { Associatio }}$ & Semantic closeness \\
\hline $\mathbf{S a S}$ & Freedom & $\begin{array}{l}\text { labour rights, minority rights, sui juris, equal opportunities. } \\
\text { freedom, responsibility, equality, vested interest, human } \\
\text { rights }\end{array}$ \\
\hline SaS & Chaos & freedom, media, sui juris \\
\hline $\mathrm{SaS}$ & Deceit & $\begin{array}{l}\text { good society. prosperity for all, equal opportunities, free- } \\
\text { dom, social security, media, voter participation, minority } \\
\text { rights }\end{array}$ \\
\hline SaS & State & social security. comption \\
\hline $\mathbf{S a S}$ & Stupidity & $\begin{array}{l}\text { minority rights, human rights, responsibility. welfare state. } \\
\text { comuption, social security, media }\end{array}$ \\
\hline SaS & $\begin{array}{l}\text { Necessity, } \\
\text { Need }\end{array}$ & $\begin{array}{l}\text { democracy, discussion, sui juris, hierarchy, labour rights, so- } \\
\text { cial security, voter participation, family, good society, sui } \\
\text { juris. freedom, welfare state, vested interest. corruption, } \\
\text { poverty, responsibility, labour, good society, human rights }\end{array}$ \\
\hline $\mathbf{S a S}$ & Equality & $\begin{array}{l}\text { minority rights, labour rights, equal opportunities, welfare } \\
\text { state, human rights, prosperity for all }\end{array}$ \\
\hline $\mathrm{SaS}$ & Justice & equality \\
\hline SaS & Election & voter participation \\
\hline $\begin{array}{l}\text { SDKÜ- } \\
\text { DS }\end{array}$ & Freedom & sui juris, freedom, discussion, human rights \\
\hline $\begin{array}{l}\text { SDKÚ- } \\
\text { DS }\end{array}$ & Equality & $\begin{array}{l}\text { welfare state, social security, good society, equal opportuni- } \\
\text { ties, solidarity. labour rights }\end{array}$ \\
\hline
\end{tabular}

Source: author 


\subsection{Social security (SMER-SD)}

The concept of social security becomes the fourth most relevant concept among the voters of the SMER-SD party. The concept of social security and its social representations are illustrated by Graph No.7

Graph 7: Concept of social security - social representations (\%)

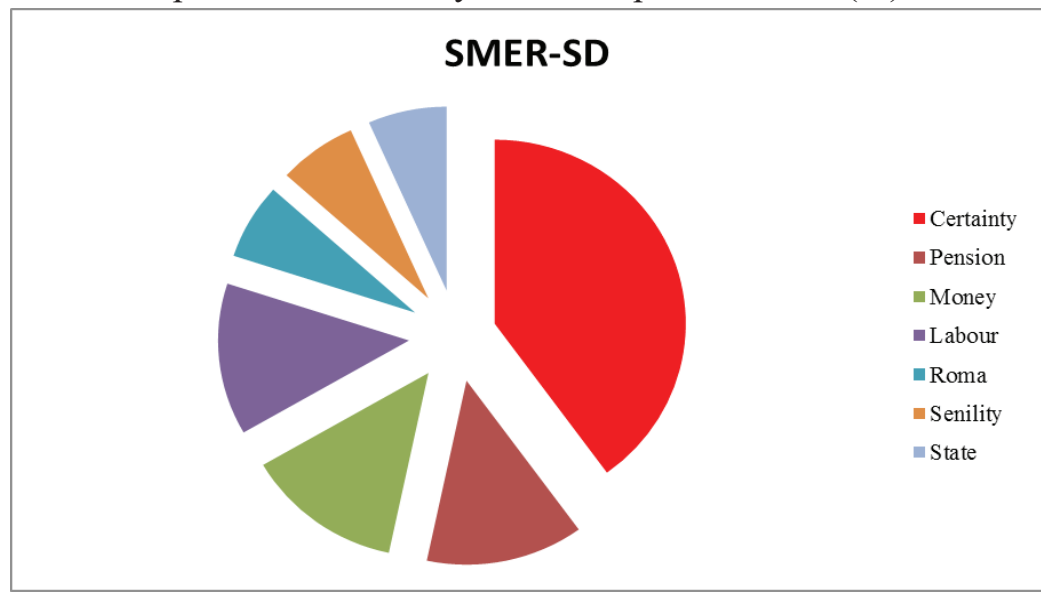

Source: author

Table 7: Concept of social security - semantic closeness

\begin{tabular}{|l|l|l|}
\hline $\begin{array}{l}\text { Political } \\
\text { party }\end{array}$ & $\begin{array}{l}\text { Associatio } \\
\mathbf{n}\end{array}$ & Semantic closeness \\
\hline SMER-SD & Certainty & $\begin{array}{l}\text { labour, labour rights good society, human rights, } \\
\text { responsibility, welfare state }\end{array}$ \\
\hline SMER-SD & Pensioner & human rights \\
\hline SMER-SD & Money & $\begin{array}{l}\text { labour, corruption, democracy, good society, equal } \\
\text { opportunities, prosperity for all, vested interest, } \\
\text { corruption }\end{array}$ \\
\hline SMER-SD & Labour & $\begin{array}{l}\text { responsibility, human rights, family, labour } \\
\text { rights, prosperity for all, equal opportunities }\end{array}$ \\
\hline SMER-SD & Roma & $\begin{array}{l}\text { poverty, minority rights, equality, sui juris, human } \\
\text { rights }\end{array}$ \\
\hline
\end{tabular}

Source: author 
From this point of view, the meaning of certainty is understood as a sign of the party identification. In addition to this, it is not surprising to notice the semantic correlation between the concept of certainty and the concepts of pension, labour, money since the party made their billboard massive under a certainty-related slogan.

The concept of social security becomes the most relevant attribute,or value only among the SMER-SD voters. This fact reflects the party identification, or at least the party discourse. Moreover, we assume that the semantic closeness examples/results being shown in the table below also reveal the target group of the SMER-SD voters. Consequently, the concept of social security is perceived as a certainty being based on labour, welfare state and therefore labour rights must be defended. Furthermore, the concept of social security correlates with the concept of pensioner; following the triad being produced along with the term human rights, however, there is a controversy over whether that link is intended to be either a negation, the denial of human rights and welfare services to pensioners, or a natural continuum of care being perceived as a fundamental human right for each group.

In this part, the main focus is held on the meaning of social security among voters. In addition to this, the concept of social security is understood as material security without addressing the higher values of life.

From this point of view, the cluster of the main association of labour reflects ideological identity. Labour and family care is the only responsibility of an individual. This correlation highlights the link between the concepts of equality and labour rights, which could lead to a good society.

\subsection{Equal opportunities (SDKÚ-DS)}

The concepts of equal opportunities, equality, democracy becomes the fifth most relevant concept among the voters of the SDKÚ-DS party. The concept of equal opportunities and its social representations are illustrated by Graph No.8.

Having analyzed social representations of the concept of equal opportunities, we identified two sub-categories. The first sub-category covers the concept of equal opportunities complying with the concepts of labour rights, solidarity, welfare state. It is interesting to see that these concepts and values are a consistent feature of socialist ideologies. The second sub-category covers a sceptical area in which non-existence of equal opportunities correlates with the concepts of social security, prosperity for all. 
Graph 8: Concept of equal opportunities - social representations (\%)

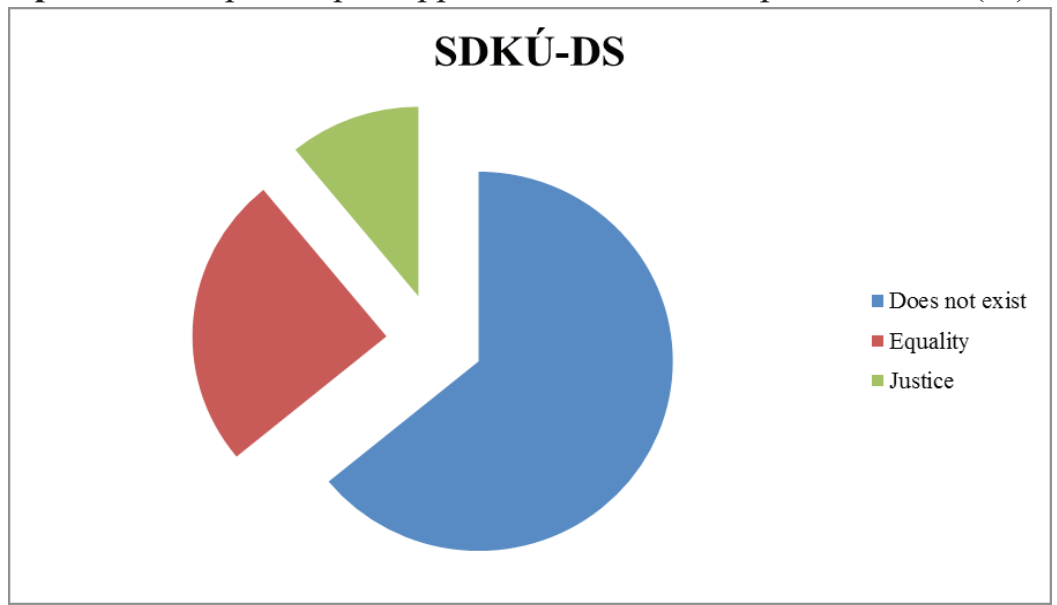

Source: author

Table 8: Concept of equal opportunities - semantic closeness

\begin{tabular}{|c|c|l|}
\hline $\begin{array}{c}\text { Political } \\
\text { party }\end{array}$ & Association & \multicolumn{1}{|c|}{ Semantic closeness } \\
\hline SDKÚ-DS & Does not exist & $\begin{array}{l}\text { discussion, vested interest, good society, prosperity for } \\
\text { all, minority rights, responsibility, equality, freedom, so- } \\
\text { cial security, labour rights, labour, equality }\end{array}$ \\
\hline SDKÚ-DS & Equality & $\begin{array}{l}\text { democracy, welfare state, social security, good society, } \\
\text { equality, solidarity, labour rights, equality }\end{array}$ \\
\hline SDKÚ-DS & Justice & democracy, welfare state, labour rights, solidarity \\
\hline
\end{tabular}

Source: author

\section{DISCUSSION}

First, in relation to the concepts to which the highest relevance is attached these are in a strong compliance with the semantic structures and social representations. This situation may be noticed when dealing with the concepts of family, labour, responsibility. 
Second, each concept of the highest relevance made by each group reflects more or less socio-cultural discourse rather than political discourse by each group. In addition to this, the semantic structures within each group are not linked to the ideological basis of a particular political party; they are similar.

Third, the concepts of social security, equal opportunities are a sign of party identification; the concepts are seen as either the most important by one group or not included/mentioned by the other. In relation to the party affiliation there are differences as to the frequency of using individual concepts, or semantic structures within all concepts; among the SMER-SD voters the concept of certainty is associated with the concepts of social security, labour rights, welfare state. Furthermore, SaS voters reiterate the concepts of arguments and discussion. In relation to SDKÚ-DS the production of associative words does not offer anything specific.

Fourth, there are clear similarities between the SaS and SDKÚ-DS voters in relation to the associative word production and semantic structures.

To sum up, the concepts which are firmly anchored in our culture/society reflect general discourse that is typical of our culture/society. In relation to the particular concepts this type of discourse becomes dominant and prevailing in comparison with political discourse. One may assume that the most commonlyused concepts reflect socio-cultural discourse, while the concepts which are not frequently used reflect political discourse, or a sign of partisan identification.

\section{CONCLUSION}

The research reflects individual political concepts and terms which are being evaluated and discussed by the particular voters; the main focus is held on the way how these concepts are understood.

We may fairly conclude that the party identification and the party discourse do not play a central role in the minds of the voters. From our point of view, policy choices made by the particular voters are not based on the unreserved party affiliation. There is a factor of nostalgia for the party, a factor of charisma being attached to the leaders.

In addition to this, it also depends on the media and the way how the party is being promoted. We assume that handling of the socially anchored social representations leads to the tactics employed to mislead voters for the benefit of the party. Furthermore, Róbert Fico, the SMER-SD leader is talented to handle effectively with the social representations and positions which are deeply rooted in our culture/society and shared by many people. 
All in all, the ideological party affiliation becomes the social order rather than a starting way of thinking, decision-making and solving of specific sociopolitical issues.

\section{REFERENCES}

ALBERTSON, BL 2011, 'Religious Appeals and Implicit Attitudes', Political psychology, vol. 32, no. 1, pp. 109-130.

BURDEIN, I, LODGE, M \& CHARLES, T 2006,'Experiments on the Automaticity of Political Beliefs and Attitudes', Political Psychology, vol. 27, no. 3, pp. 359-371.

FÉLIX, N 2009, 'Implicit and explicit attitudes among students', Universitas Psychologica, vol. 8, n. 3, pp. 849-857.

MORELAND, RL \& BEACH, SR 1992, 'Exposure effects in the classroom: The development of afinity among students', Journal of Experimental Social Psychology, vol. 28, no. 3, pp. 255-276.

PLICHTOVÁ, J 2002, Metódy sociálnej psychológie zblizka: Kvalitativne a kvantitatívne skúmanie sociálnych reprezentácií. Média, Bratislava.

VAN DIJK, AT 2003, Ideology and discourse. A Multidisciplinary Introduction, Ariel, Barcelona. Available from: Discourse in Society [6 May 2015]. 